\title{
PERITONEAL DIALYSIS-RELATED PERITONITIS: RATE, CLINICAL OUTCOMES AND PATIENT SURVIVAL
}

\section{Pavlina Dzekova-Vidimliski ${ }^{1}$, Igor G. Nikolov ${ }^{1}$, Nikola Gjorgjievski ${ }^{1}$, Gjulsen Selim ${ }^{1}$, Lada Trajceska ${ }^{1}$, Ana Stojanoska ${ }^{1}$, Irena Rambabova-Bushljetik ${ }^{1}$, Risto Simeonov ${ }^{2}$, Ljupco Stojkovski ${ }^{2}$}

${ }^{1}$ University Hospital of Nephrology, Skopje, R. North Macedonia

${ }^{2}$ Acibadem Sistina Hospital, Skopje, R. North Macedonia

Corresponding author: Pavlina Dzekova-Vidimliski, University Hospital of Nephrology, Skopje, R. North Macedonia, e-mail: pavlinadzekova@yahoo.com

\begin{abstract}
Peritoneal dialysis-related peritonitis remains the major complication and primary challenge to the longterm success of peritoneal dialysis (PD). The study aimed to analyze the peritonitis rate, the cause, the outcomes, and the association of peritonitis with the survival of patients on peritoneal dialysis. Patient data were collected retrospectively from medical charts. A total of 96 patients received peritoneal dialysis in the PD center from 1 January 1999 to 31 December 2018. Episodes of peritonitis $(n=159)$ were registered in $54(56.3 \%)$ patients. The study population was divided into two groups, a group of patients $(n=54)$ who experienced peritonitis and a group of patients free of peritonitis $(n=42)$. The peritonitis rate was 0.47 episodes per patient year. The majority of causative microorganisms were gram-positive bacteria $(53.5 \%)$. Outcomes of the episodes of peritonitis were resolved infection in $84.9 \%$ of episodes, catheter removal in $11.3 \%$ of episodes, and death in $3.8 \%$ of the episodes of peritonitis. A Kaplan-Meier analysis and log-rank test revealed that the group with peritonitis tended to survive significantly longer than the peritonitis-free group. A $67 \%$ reduction rate in the risk of patient mortality was observed for the peritonitis group compared with the peritonitis-free group (hazard ratio: $0.33,95 \% \mathrm{CI} 0.19-0.57, \mathrm{P}=0.000$ ). The prevention and management of PD-related infections, resulted in their worldwide reduction, supporting the use of PD as a first-line dialysis modality.
\end{abstract}

Keywords: peritoneal dialysis, infection, bacteria, peritonitis, survival

\section{INTRODUCTION}

Peritoneal dialysis (PD) is a high quality and cost-effective dialysis modality, and it is a part of kidney replacement therapy (KRT) for the treatment of kidney failure (KF) [1]. The relative use of peritoneal dialysis versus hemodialysis varies widely in different regions of the world. The percentage of patients with kidney failure treated with peritoneal dialysis was $5 \%$ -
$10 \%$ in economically developed regions like the United States and Western Europe. The percentage of $75 \%$ was registered in Mexico, as a less economically developed region, where PD was the first choice for KRT, due to higher costs and difficulty accessing a hemodialysis unit [2].

Over the past decade, treatment practice and technical improvements in peritoneal dial- 
ysis have substantially decreased PD-associated adverse outcomes, although PD-related peritonitis remains the major complication and primary challenge to the long-term success of peritoneal dialysis [3]. Peritonitis may lead to structural and functional alterations of the peritoneal membrane, like peritoneal fibrosis and even encapsulating peritoneal sclerosis, a rare but devastating complication of long-term PD. Additionally, PD-related peritonitis resulted in significant morbidity, hospital admission, and cessation of the PD program [4]. It also considerably limits its choice as a KRT modality among patients with kidney failure. Importantly, PD-related peritonitis contributed up to $60 \%$ of the technical failure of $P D$, necessitating a subsequent switch to a long-term hemodialysis treatment $[5,6]$. Peritonitis rates varied across regions and countries, ranging from 0.20 to 0.82 episodes per patient-year of treatment [7-10].

The PD catheter is the source of infection for the vast majority of PD-related peritonitis. The catheter provides a portal of entry for microorganisms into the normally sterile peritoneum. Most cases of PD-related peritonitis are the result of "touch contamination", where the patient or their helper accidentally breaks the sterile technique and contaminates the catheter or its connections. The most common microbial cause of "touch contamination" is gram-positive bacteria $[11,12]$. A small percentage of PD-related peritonitis results from exit-site or tunnel infections, in which organisms spread down through the catheter tunnel outside from the catheter itself to the peritoneum. The most common microbial cause of exit-site infection is Staphylococcus aureus and Pseudomonas aeruginosa [13]. Less commonly, diverticulitis, appendicitis, and cholecystitis may be the source for pathogens for peritonitis, as well as intra-abdominal surgery, colonoscopy, hysteroscopy, and transmigration of bowel flora from constipation. In cases with an intra-abdominal source, the pathogens are usually gram-negative enteric bacteria and anaerobic bacteria [14].

Some studies have shown that peritonitis had a negative impact on mortality in PD patients [7, 15], although this was not confirmed by other studies [16]. The risk for mortality was increased among patients with longer PD duration who experienced a peritonitis event $[15,17]$.

The study aimed to analyze the peritonitis rate, the microbiological cause of infection, clin- ical outcomes, and the association of peritonitis with the survival of patients.

\section{PATIENTS AND METHODS}

\section{Study population}

A total of 96 patients received peritoneal dialysis as kidney replacement therapy in our PD center from 1 January 1999 to 31 December 2018. The mean age of the population was $46.8 \pm$ 16.4 years, $58.3 \%$ were male and $13.5 \%$ had diabetes mellitus. The most common primary renal disease was chronic glomerulonephritis (41.7\%), followed by nephrosclerosis (25\%). The PD catheter (Tenckhoff) was implanted by open surgery. Patient training was started soon after PD catheter implantation, followed by retraining after each episode of peritonitis. The patients were instructed to perform daily wound care with a normal saline wash followed by the application of povidone-iodine to the skin surface around the exit site. There was no routine wound care with topical mupirocin or gentamicin cream or ointment, only with indication. Routine screening for nasal Staphylococcus aureus colonization was performed for every patient before starting with PD therapy. Conventional PD solutions in twinbag systems (Dianeal 1.36\%, 2.27\%, or 3.86\% glucose, and Extranel, Baxter Healthcare SA, Castlebar, Ireland) were utilized in over $96 \%$ of patients, performing continuous ambulatory PD (CAPD). The rest of the patients were performing automated PD (APD). The study population was divided into two groups, a group of patients $(n=54)$ who experienced peritonitis and a group of patients free of peritonitis $(n=42)$.

\section{Methods}

Data were collected retrospectively from medical charts from the patients in the PD center.

The retrospective observational study was conducted in compliance with the ethical principles of the Helsinki Declaration. Baseline patient data included age, gender, primary renal disease, date of PD catheter implantation, date of starting PD, PD modality (CAPD or APD), data for episodes of peritonitis (pathogen and clinical outcome), and cause of death. When the patient reported symptoms associated with peritonitis, such as cloudy effluent, abdominal pain, and/or fever, peritoneal effluent was collected and ana- 
lyzed. The effluent was cultured in 2 blood culture-bottles. If the white blood cell (WBC) count in peritoneal effluent was elevated $(>100$ cells/ $\mu \mathrm{L})$ with polymorphonuclear neutrophil predominance $(>50 \%)$, an empirical intraperitoneal antibiotic was administrated immediately after culture collection. The empirical regimen was vancomycin for gram-positive and amikacin for gram-negative bacteria. The patients were followed up for 2 to 7 days after the first antibiotic dose. Hospitalization was indicated for patients with high fever and toxic signs, severe abdominal pain, and fluid overload. Effluent cultures and fluid analysis were repeated if there was no clinical improvement after 3 to 5 days of antibiotic treatment.

Follow-up of patients was censored at renal transplantation, hemodialysis transfer, death, or until the end of the study period (31 December 2018). Hemodialysis transfer was defined as a transfer from peritoneal dialysis to hemodialysis treatment without return to peritoneal dialysis within 30 days. Death of patients while on PD treatment and 30 days after censoring PD therapy were considered as mortality in this study. The outcomes were peritonitis-related mortality and cardiovascular mortality.

\section{STUDY DEFINITIONS}

The diagnosis of PD-related peritonitis requires any two of the following features: (1) abdominal pain and/or cloudy peritoneal effluent; (2) effluent WBC count of more than 100 cell $/ \mu \mathrm{L}$ (after a dwell time of at least 2 hours) with more than $50 \%$ neutrophils, and (3) positive result of the effluent culture [14]. Relapsing peritonitis was defined as an episode that occurs within 4 weeks of completion of therapy of a prior episode with the same pathogen. Recurrent peritonitis represents an episode that occurs within 4 weeks of completion of a therapy of a prior episode but with a different pathogen. Repeat peritonitis was defined as an episode that occurs more than 4 weeks after completion of therapy of a prior episode with the same pathogen. Refractory peritonitis was defined as a failure of the peritoneal effluent to clear up after 5 days of appropriate antibiotic treatment [14]. Catheter-related infection is used as the collective term to describe both exit-site infection and tunnel infection. Exit-site infection (ESI) is diagnosed by the presence of purulent drainage, with or without erythema of the skin at the catheter-epidermal interface. Tunnel infection is defined as the presence of clinical inflammation or ultrasonographic evidence of collection along the catheter tunnel. Catheter-related peritonitis represents peritonitis in conjunction with an exit-site or tunnel infection with the same pathogen [13]. Outcomes of peritonitis episodes were classified as cure, technique failure, and death. A cure was defined as the resolution of the episode of peritonitis without relapse or recurrence, by antibiotics alone and continuation of PD therapy. Technique failure was defined as the permanent transfer to hemodialysis therapy because of PD-related infection, ultrafiltration failure by PD, presence of any mechanical problem, or the patient's choice [14]. Death related to peritonitis was defined as the death of a patient with active peritonitis or within 30 days of an episode of peritonitis [7]. Cardiovascular death was defined as death because of ischemic heart disease, arrhythmias, congestive heart failure, sudden cardiac death, other heart diseases, or cerebrovascular events [18].

\section{STATISTICAL ANALYSIS}

Statistical analysis was performed using SPSS, version 17.0 for Windows (SPSS, Chicago, IL, USA). Results were expressed as mean \pm standard deviation (SD) for continuous variables and frequencies and percentages for categorical variables. Differences between the two groups of patients with and without peritonitis were tested using Student's t-test and the Chi-square test. The Kaplan-Meier analysis and log-rank statistics were used to compare survival between patient groups based on the presence or absence of peritonitis. Cox proportional hazards regression was used to select significant factors associated with survival. A $P$ value less than 0.05 was considered statistically significant.

\section{RESULTS}

From 1 January 1999 to 31 December 2018, 96 patients with kidney failure were treated with peritoneal dialysis in the center. The 
mean age of patients was $46.8 \pm 16.4$ years, and the meantime receiving peritoneal dialysis was $3.5 \pm 3.1$ years. A total of 159 episodes of peritonitis occurred in $54(56.3 \%)$ patients. The average number of episodes of peritonitis was 2.9 episodes per patient. Single episode of peritonitis was registered in $24(44.4 \%)$ patients. More than 3 episodes of peritonitis were registered in $21(38.9 \%)$ patients. The demographic characteristics of the two groups of patients, patients who experienced peritonitis and patients free of peritonitis, are shown in Table 1.

The peritonitis rate was 0.47 episodes per patient-year (1 episode per 25.5 months).
The rates of recurrent, relapsing, repeat, and refractory peritonitis were $0.6 \%, 12 \%, 8.8 \%$, and $8.8 \%$, respectively. There were also 15 episodes of catheter-related infections: 12 episodes of exit-site infection and 3 episodes of tunnel infection. Seven episodes of exit-site infection were complicated with peritonitis.

The majority of causative microorganisms were gram-positive bacteria (53.5\%). Coagulase-negative staphylococci (CoNS) were the most common isolated gram-positive bacteria, followed by Staphylococcus aureus, Methicillin-resistant Coagulase-negative staphylococci (MR-CoNS), and Streptococci (Table 2).

Table 1. The demographic characteristics of the two groups of patients, patients with experienced peritonitis, and patients free of peritonitis.

\begin{tabular}{|c|c|c|c|}
\hline & Patients with peritonitis & $\begin{array}{c}\text { Patients free of } \\
\text { peritonitis }\end{array}$ & $\mathrm{P}$ \\
\hline Number (\%) & $54(56.3 \%)$ & $42(43.7 \%)$ & \\
Age at PD* start (years) & $47.9 \pm 16.4$ & $44.7 \pm 16.5$ & 0.339 \\
Gender (male, n, \%) & $27(50 \%)$ & $27(64 \%)$ & 0.214 \\
Diabetes mellitus (n, \%) & $9(16.7 \%)$ & $8(19.0 \%)$ & 0.793 \\
PD* vintage (years) & $4.5 \pm 3.5$ & $2.2 \pm 1.7$ & 0.000 \\
\hline
\end{tabular}

*peritoneal dialysis

Table 2. Causative microorganisms for episodes of peritonitis, exit-site infections, and tunnel infections

\begin{tabular}{|c|c|c|c|c|c|c|}
\hline \multirow[t]{2}{*}{ Microorganism } & \multicolumn{2}{|c|}{ Peritonitis $(n=159)$} & \multicolumn{2}{|c|}{$\begin{array}{c}\text { Exit-site } \\
\text { infection }(n=12)\end{array}$} & \multicolumn{2}{|c|}{$\begin{array}{c}\text { Tunnel } \\
\text { infection }(n=3)\end{array}$} \\
\hline & n & $\%$ & $\mathbf{n}$ & $\%$ & $\mathbf{n}$ & $\%$ \\
\hline Gram-positive bacteria & 85 & 53.5 & 10 & 83.3 & 3 & 100 \\
\hline Stapylococcus aureus & 21 & 13.2 & 6 & 50.0 & 3 & 100 \\
\hline Methicillin resistance stapylococcus aureus & 2 & 1.3 & 0 & & 0 & \\
\hline Coagulasa-negative staphylococci & 31 & 19.5 & 1 & 8.3 & 0 & \\
\hline Coagulasa-negative staphylococci $M R$ & 11 & 6.9 & 3 & 25.0 & 0 & \\
\hline Streptococci & 10 & 6.3 & 0 & & 0 & \\
\hline Enterococci & 5 & 3.1 & 0 & & 0 & \\
\hline Other gram-positive bacteria & 5 & 3.1 & 0 & & 0 & \\
\hline Gram-negative bacteria & 27 & 17.0 & 2 & 16.7 & 0 & \\
\hline Escherichia coli & 14 & 8.8 & 0 & & 0 & \\
\hline Klebsiela species & 3 & 1.9 & 0 & & 0 & \\
\hline Pseudomonas aeruginosa & 8 & 5.0 & 2 & 16.7 & 0 & \\
\hline Other gram-negative bacteria & 2 & 1.3 & 0 & & 0 & \\
\hline Fungi & 3 & 1.9 & 0 & & 0 & \\
\hline Candida species & 2 & 1.3 & 0 & & 0 & \\
\hline Gerotrichium & 1 & 0.6 & 0 & & 0 & \\
\hline Polymicrobial infection & 4 & 2.5 & 0 & & 0 & \\
\hline Culture negative & 23 & 14.5 & 0 & & 0 & \\
\hline No cultured effluent & 17 & 10.7 & 0 & & 0 & \\
\hline
\end{tabular}


Gram-negative bacteria constituted $17 \%$ of causative microorganisms, and Escherichia coli was the most common isolated gram-negative bacteria (Table 2). There were $3(1.9 \%)$ fungal peritonitis episodes. Culture negative results were present in $23(14.5 \%)$ episodes. In $17(10.1 \%)$ episodes of peritonitis, there was no collection of effluent for culture. Escherichia coli was associated with refractory peritonitis. Staphylococcus aureus was the most common pathogen for both exit-site and tunnel infections (Table 2).

Outcomes of the episodes of peritonitis were: either completely resolved infection or

Table 3. Outcomes from episodes of peritonitis and catheter-related infections

\begin{tabular}{|l|ll|}
\hline & $\mathrm{n}$ & $\%$ \\
Outcomes of episodes of peritonitis & $\mathbf{1 5 9}$ & $\mathbf{1 0 0}$ \\
Completed resolved infection or cure & 135 & 84,9 \\
Catheter removal & 18 & 11,3 \\
refractory peritonitis & 7 & \\
repeat peritonitis & 4 & \\
relapsing peritonitis & 3 & \\
fungal peritonitis & 3 & \\
catheter related peritonitis & 1 & \\
Re-insertion of new PD catheter & 5 & \\
Death & 6 & 3,8 \\
Outcomes of catheter-related & & \\
infection & $\mathbf{1 5}$ & $\mathbf{1 0 0}$ \\
Completed resolved infection or cure & 13 & 86,7 \\
Catheter removal & 2 & 13,3 \\
refractory exit-site infection & 1 & \\
repeat tunnel infection & 1 & \\
\hline
\end{tabular}

cure presented in $135(84.9 \%)$ episodes, catheter removal in $18(11.3 \%)$ episodes, and death in $6(3.8 \%)$ episodes of peritonitis. Surgery to remove the peritoneal catheter was required in 18 episodes of peritonitis, and patients were transferred to hemodialysis treatment. Indications for catheter removal are presented in Table 3. Re-insertion of a new PD catheter was performed after complete resolution of peritoneal symptoms in 5 episodes of peritonitis. Outcomes of catheter-related infection were completely resolved infection in $13(86.7 \%)$ episodes and catheter removal in $2(13.3 \%)$ episodes, Table 3 . Technique failure or permanent transfer to hemodialysis treatment due to PD-related infection was an outcome from 15 episodes.

By the end of the follow-up period, 17 $(17.7 \%)$ of the 96 patients remained on PD, 29 $(30.2 \%)$ patients were transferred to hemodialysis, $15(15.6 \%)$ patients received renal transplantation and $35(36.5 \%)$ had died. The causes for technical failure were: the PD-related infection in 15 patients, ultrafiltration failure in 2 patients, leakage in 7 patients, migration of PD catheter in 2 patients and the patient's choice with inability to practice PD in 3 patients.

Of the 35 deaths, $29(82.9 \%)$ of the patients died from cardiovascular diseases, while 6 (17.1\%) patients died from infection associated with the episodes of peritonitis. A Kaplan-Meier analysis and log rank test revealed that there was a significant difference in survival between the groups, the group experiencing peritonitis tended to survive longer than the group that was peritonitis-free (Graphic 1). Cox regression anal-

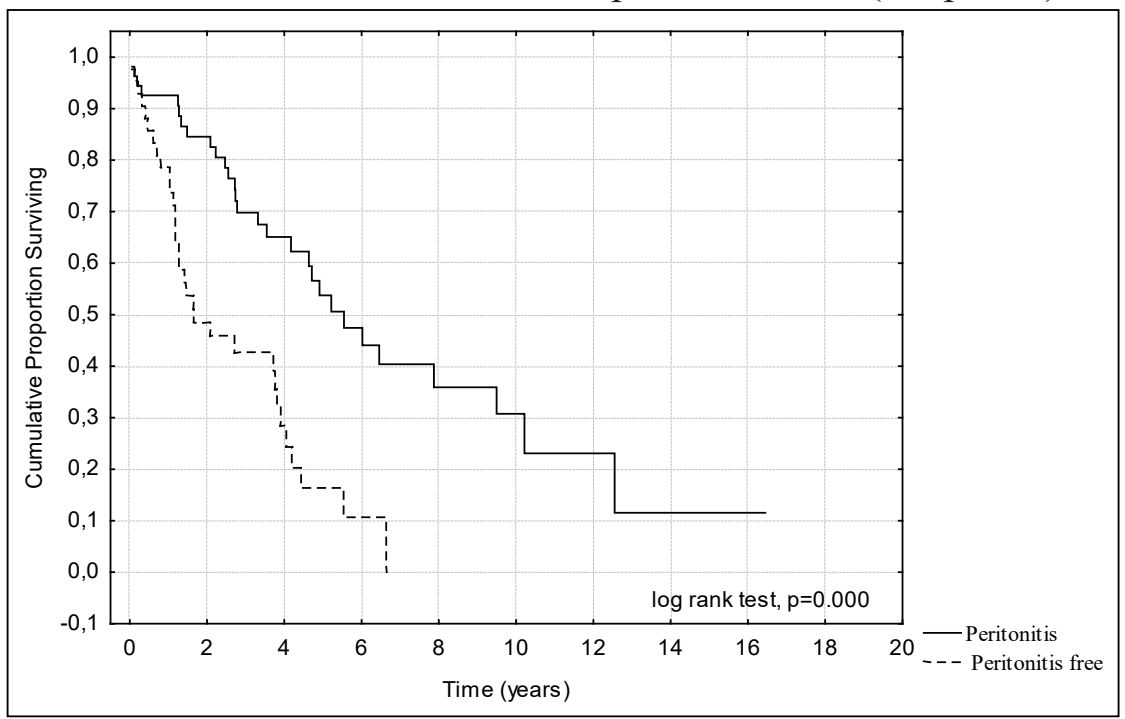

Graphic 1. Kaplan-Meier analysis of the survival between the group experiencing peritonitis and the peritonitis free group. 
ysis demonstrated that peritonitis was a predictor associated with improved survival of patients, a $67 \%$ reduction in the risk of patient mortality was observed for the group experiencing peritonitis compared with the peritonitis-free group, (hazard ratio: $0.33,95 \%$ CI 0.19-0.57, $\mathrm{P}=0.000$ ).

\section{DISCUSSION}

Prevention and management of peritonitis are essential for the long-term success of peritoneal dialysis. Over the past 30 years, recommendations regarding the treatment and prevention of PD-related peritonitis were published and revised regularly under the auspices of the International Society for Peritoneal Dialysis (ISPD). The ISPD recommendations emphasized that every PD program should monitor the PD-related peritonitis rate at least every year and the rate should be reported as the number of episodes per patient-year of treatment. The 2016 ISPD guidelines recommended that the overall peritonitis rate should be below 0.5 episodes per patient-year or one episode every 24 months [14]. The overall peritonitis rate of our center was 0.47 episodes per patient-year or one episode in every 25.5 months of treatment. The overall peritonitis rates, in episodes per patient-year, in countries participating in the Peritoneal Dialysis Outcomes and Practice Patterns Study (PDOPPS) were: 0.40 in Thailand, 0.38 in the United Kingdom, 0.35 in Australia/New Zealand, 0.29 in Canada, 0.27 in Japan, and 0.26 in the United States [19].

Most of the episodes of peritonitis are caused by gram-positive bacteria. Gram-positive bacteria, identified in $85(53.5 \%)$ episodes of peritonitis, were also the most common pathogen in our center. Gram-positive bacteria were the cause of peritonitis in $52 \%-57 \%$ of episodes in other studies [20, 21]. Staphylococcus aureus colonizes nares and skin, as well as disruptions of the skin (exit site) in many patients, and it is a common cause of exit-site and tunnel infections [22]. This pathogen was the cause of $83.3 \%$ of the episodes of exit-site infection and for $100 \%$ of episodes of tunnel infection in our center. In most case series of peritonitis, gram-negative bacteria account for $10 \%$ to $25 \%$ of cases. Despite optimal antibiotic therapy, episodes of peritonitis caused by gram-negative bacteria were characterized by relatively high failure rates, catheter removal, permanent transfer to hemodialysis, and death [22]. Gram-negative bacteria were identified in $27(17 \%)$ episodes of peritonitis in our center. Escherichia coli accounted for more than half of cases of peritonitis caused by gram-negative bacteria and it was associated with refractory peritonitis. Escherichia coli infections were significantly associated with refractory peritonitis in the study of Wang $\mathrm{HH}$ et al. [23]. The prevalence of fungal peritonitis varies from center to center, from $1 \%$ to $15 \%$ of cases [24]. Candida spp. accounted for $90 \%$ or more of episodes of fungal peritonitis. Most cases of Candida peritonitis followed a recent course of antibiotics for peritonitis or other indications. The ISPD guidelines recommend immediate catheter removal upon diagnosis of fungal peritonitis because of the refractory course [14, $24]$. There were $3(1.9 \%)$ episodes of fungal peritonitis with immediate catheter removal upon diagnosis in our center. Unfortunately, effluent cultures do not always yield a microorganism in patients with peritonitis. ISPD guidelines recommend a benchmark of $20 \%$ culture-negative cases [14]. The percentage of culture-negative cases was $14.5 \%$ in our center. In culture-negative cases, the likely pathogen was a gram-positive organism, most often Coagulase-negative staphylococcus, and gram-negative coverage could be discontinued. Other causes of culture-negative cases were infection with fastidious bacterial organisms, acid-fast bacilli (AFB), or fungal organisms. In these cases, if clinical improvement in symptoms and decrease in peritoneal WBC count has not occurred after 3 days of empiric antibiotic therapy and initial effluent culture remained negative after 3 days, the initial peritoneal effluent-culture bottles should be subcultured onto solid media and enriched liquid media like thioglycolate. Also, effluent should be obtained and cultured for fungi and AFB [14].

Prompt clinical diagnosis and early initiation of antibiotic therapy are key to the successful treatment of peritonitis. Therefore, patients presenting with cloudy effluent should be presumed to have peritonitis and treated as such until the diagnosis is confirmed or excluded [14]. Antibiotics should be administered intraperitoneally in PD-related infections unless there are features of systemic sepsis [14]. The advantages of intraperitoneally administered antibiotics include the delivery of a high concentration of antibiotic at the site of infection. Intraperitoneally administered antibiotics are also absorbed 
into the systemic circulation with diffusion back into the peritoneum, allowing daily or less frequent administration. For empiric coverage of gram-positive bacteria, recommended drugs are cefazolin or vancomycin. For empiric coverage of gram-negative bacteria, initial therapy should include a third-generation cephalosporin or an aminoglycoside. The effluent culture and susceptibility results should be available in 3-5 days, and antibiotic therapy could be focused on a single agent. If the patient has not responded clinically after $3-5$ days from the start of antibiotic therapy, a repeat peritoneal effluent sample should be cultured for unusual pathogens. [22] Antifungal prophylaxis, nystatin orally every 24 hours or fluconazole $200 \mathrm{mg}$ orally every 48 hours, should be added to initial antibiotic therapy in order to prevent secondary fungal peritonitis [14, 25].

The indications of PD catheter removal are: refractory peritonitis, relapsing peritonitis, fungal peritonitis, and refractory exit-site or tunnel infection. Catheter removal may also be considered in repeat peritonitis, mycobacterial peritonitis, and peritonitis from multiple enteric microorganisms. Reinsertion of a new PD catheter and return to PD is possible, but should be performed at least 2 weeks after catheter removal and complete resolution of peritoneal symptoms [14]. Reinsertion should be made only after waiting for $4-6$ weeks in the case of fungal peritonitis [24]. In our center, catheter removal was indicated in 18 episodes of peritonitis, and 2 episodes of a catheter-related infection (Table 3 ). Reinsertion of a new PD catheter and successful return to the PD program was performed after catheter removal and resolution of infection in 5 episodes of peritonitis, and one of the episodes was fungal peritonitis caused by Gerotrichium.

Peritonitis is the most frequent cause of technique failure. It is the permanent transfer of patients from PD to HD. [22] A multi-center study from Scotland showed that $42.6 \%$ of PD patients were transferred to HD permanently because of refractory or recurrent peritonitis, with a significant correlation between peritonitis and technique failure. [26] Other studies referred that peritonitis was the main cause of technique failure in $46.9 \%$ to $60 \%$ of the cases transferred to HD permanently $[6,10]$. PD related infections were the main cause of technique failure in $52 \%$ of the cases transferred to HD permanently in our center.
Cardiovascular diseases are a frequent and important cause of morbidity and mortality in patients with kidney failure and account for up to $50 \%$ of all deaths in studies. [10] Most of the patients $(82.9 \%)$ died due to cardiovascular diseases. The infection from episodes of peritonitis was the cause for mortality in $17.1 \%$ of cases. The reported prevalence of peritonitis-associated mortality in the literature varies from $5.9 \%$ up to $33 \%$ of deaths. $[7,10]$ The impact of peritonitis on patient mortality, according to the presence or absence of peritonitis, was studied in this observational study. The survival of the group experiencing peritonitis was significantly longer than the survival of the peritonitis-free group (Graphic 1). Another study from Taiwan reported that PD patients with peritonitis had a lower risk of all-cause mortality in comparison with patients without peritonitis. [16] The retrospective observational cohort study enrolled 391 patients treated with CAPD between 1 January 2001 and 31 December 2010. The peritonitis rate was 0.196 episodes per patient-year. A Kaplan-Meier analysis revealed that the group experiencing peritonitis tended to have a better survival than the group that was peritonitis free. In the multivariate Cox regression model, a 36\% reduction in the risk of patient mortality was observed for the group experiencing peritonitis, compared with the peritonitis-free group (hazard ratio: $0.64 ; 95 \% \mathrm{CI}: 0.46-0.89 ; \mathrm{P}=0.006)$. The Taiwan study described this presumptive "peritonitis paradox" with exceptional education on self-care and management of PD complications of patients who survived the first peritonitis episode, with the possibility of facilitating their survival to a higher degree than in the patients free from peritonitis.

Other studies published that patients who survive longer on PD carry a higher risk of experiencing a peritonitis event $[15,17]$. PD treatment vintage was significantly longer in the group experiencing peritonitis compared to the peritonitis-free group $(4.5 \pm 3.5 v s .2 .2 \pm 1.7$ years, $\mathrm{P}=0.000)$ in our center.

\section{CONCLUSION}

A good PD training program is a fundamental part of a successful peritoneal dialysis program. It is generally accepted that PD train- 
ing should be conducted by nursing staff with the appropriate qualifications and experience, and the latest ISPD recommendations for teaching PD patients and their caregivers should be followed. In addition to the initial training, retraining should be considered after each episode of peritonitis or catheter infection. The implementation of ISPD guidelines for prevention and management of PD-related infections, resulted in their worldwide reduction, supporting the use of PD as a first-line dialysis modality.

\section{REFERENCES}

1. Abecassis M, Bartlett ST, Collins AJ, et al. KidHu S, Ming P, Qureshi AR, Lindholm B, Bo Y, Yang H. Peritonitis: Episode Sequence, Microbiological Variation, Risk Factors and Clinical Outcomes in a North China Peritoneal Dialysis Center. Kidney Blood Press Res. 2018; 43(5): 1573-84.

2. Grassmann A, Gioberges S, Moeller S, Brown G. ESRD patients in 2004: global overview of patient numbers, treatment modalities and associated trends. Nephrol Dial Transplant. 2005; 20: 2587-93

3. Li PK, Chow KM, Van de Luijtgaarden MW, Johnson DW, Jager KJ, Mehrotra R, et al. Changes in the worldwide epidemiology of peritoneal dialysis. Nat Rev Nephrol. 2017 Feb; 13(2): 90103.

4. Cho Y, Johnson DW. Peritoneal dialysis-related peritonitis: towards improving evidence, practices, and outcomes. Am J Kidney Dis. 2014 Aug; 64(2): 278-89.

5. Nochaiwong S, Ruengorn C, Koyratkoson K, Thavorn K, Awiphan R, Chaisai C, et al. Thai Renal Outcomes Research (THOR) Investigators. A Clinical Risk Prediction Tool for Peritonitis-Associated Treatment Failure in Peritoneal Dialysis Patients. Sci Rep. 2018 Oct 4; 8(1): 14797

6. de Moraes TP, Figueiredo AE, de Campos LG, Olandoski M, Barretti P, Pecoits-Filho R; BRAZPD Investigators. Characterization of the BRAZPD II cohort and description of trends in peritoneal dialysis outcome across time periods. Perit Dial Int. 2014 Nov-Dec; 34(7): 714-23.

7. Boudville N, Kemp A, Clayton P, Lim W, Badve SV, Hawley CM, et al. Recent peritonitis associates with mortality among patients treated with peritoneal dialysis. J Am Soc Nephrol 2012; 23: 1398-405

8. Nishina M, Yanagi H, Kakuta T, Endoh M, Fukagawa M, Takagi A: A 10-year retrospective cohort study on the risk factors for peritoneal dialysis-related peritonitis: a single-center study at Tokai University Hospital. Clin Exp Nephrol 2014; 18: 649-654

9. Tian Y, Xie X, Xiang S, Yang X, Lin J, Zhang X, et al. Risk Factors and Outcomes of Early-Onset Peritonitis in Chinese Peritoneal Dialysis Patients. Kidney Blood Press Res. 2017; 42(6): 1266-76.

10. Fang W, Qian J, Lin A, Rowaie F, Ni Z, Yao Q, et al. Comparison of peritoneal dialysis practice patterns and outcomes between a Canadian and a Chinese centre. Nephrol Dial Transplant. 2008 Dec; 23(12): 4021-28.

11. Mujais S. Microbiology and outcomes of peritonitis in North America. Kidney Int Suppl. 2006 Nov; (103): S55-62.

12. Ghali JR, Bannister KM, Brown FG, Rosman JB, Wiggins KJ, Johnson DW, et al. Microbiology and outcomes of peritonitis in Australian peritoneal dialysis patients. Perit Dial Int. 2011 NovDec; 31(6): 651-62.

13. Szeto CC, Li PK, Johnson DW, Bernardini J, Dong J, Figueiredo AE, et al. ISPD Catheter-Related Infection Recommendations: 2017 Update. Perit Dial Int. 2017 Mar-Apr; 37(2): 141-54.

14. Li PK, Szeto CC, Piraino B, de Arteaga J, Fan $\mathrm{S}$, Figueiredo AE, et al. ISPD Peritonitis Recommendations: 2016 Update on Prevention and Treatment. Perit Dial Int. 2016 Sep 10; 36(5): 481-508.

15. Ye H, Zhou Q, Fan L, Guo Q, Mao H, Huang $\mathrm{F}$, et al. The impact of peritoneal dialysis-related peritonitis on mortality in peritoneal dialysis patients. BMC Nephrol. 2017 Jun 5; 18(1): 186.

16. Hsieh YP, Chang CC, Wen YK, Chiu PF, Yang Y. Predictors of peritonitis and the impact of peritonitis on clinical outcomes of continuous ambulatory peritoneal dialysis patients in Taiwan--10 years' experience in a single center. Perit Dial Int. 2014 Jan-Feb; 34(1): 85-94.

17. Klarić D, Knotek M. Long-term effects of peritonitis on peritoneal dialysis outcomes. Int Urol Nephrol 2013; 45: 519-25

18. Cheung AK, Sarnak MJ, Yan G, Berkoben M, Heyka R, Kaufman A, et al.; HEMO Study Group. Cardiac diseases in maintenance hemodialysis patients: results of the HEMO Study. Kidney Int. 2004 Jun; 65(6): 2380-9.

19. Perl J, Fuller DS, Bieber BA, Boudville N, Kanjanabuch T, Ito Y, et al. Peritoneal Dialysis-Related Infection Rates and Outcomes: Results From the Peritoneal Dialysis Outcomes and Practice Patterns Study (PDOPPS). Am J Kidney Dis. $2020 \mathrm{Jul}$; 76(1): 42-53.

20. Burke M, Hawley CM, Badve SV, McDonald SP, Brown FG, Boudville N, et al. Relapsing and recurrent peritoneal dialysis-associated peritonitis: 
a multicenter registry study. Am J Kidney Dis. 2011 Sep; 58(3): 429-36.

21. van Esch S, Krediet RT, Struijk DG. 32 years' experience of peritoneal dialysis-related peritonitis in a university hospital. Perit Dial Int. 2014 MarApr; 34(2): 162-70.

22. Salzer WL. Peritoneal dialysis-related peritonitis: challenges and solutions. Int J Nephrol Renovasc Dis. 2018 Jun 11; 11: 173-86.

23. Wang $\mathrm{HH}$, Huang $\mathrm{CH}$, Kuo MC, Lin SY, Hsu $\mathrm{CH}$, Lee CY,et al. Microbiology of peritoneal dialysis-related infection and factors of refractory peritoneal dialysis related peritonitis: A ten-year single-center study in Taiwan. J Microbiol Immunol Infect. 2019 Oct; 52(5): 752-59.
24. Prasad N, Gupta A. Fungal peritonitis in peritoneal dialysis patients. Perit Dial Int. 2005 MayJun; 25(3): 207-22.

25. Restrepo C, Chacon J, Manjarres G. Fungal peritonitis in peritoneal dialysis patients: successful prophylaxis with fluconazole, as demonstrated by prospective randomized control trial. Perit Dial Int. 2010 Nov-Dec; 30(6): 619-25.

26. Kavanagh D, Prescott GJ, Mactier RA. Peritoneal dialysis-associated peritonitis in Scotland (1999-2002). Nephrol Dial Transplant. 2004 Oct; 19(10): 2584-91.

\title{
Резиме
}

\section{ПЕРИТОНИТ ПОВРЗАН СО ПЕРИТОНЕАЛНА ДИЈАЛИЗА: СТАПКА, КЛИНИЧКИ ИСХОДИ И ПРЕЖИВУВАњЕ НА ПАЦИЕНТИТЕ}

\author{
Павлина Џекова-Видимлиски ${ }^{1}$, Игор Г. Николов ${ }^{1}$, Никола Ѓ Грѓ́ \\ Ана Стојаноска ${ }^{1}$, Ирена Рамбабова-Бушљетиќ ${ }^{1}$, Ристо Симеонов ${ }^{2}$, Љупчо Стојковски ${ }^{2}$ \\ 1 Универзитетска клиника за нефрологија, Скопје, РС Македонија \\ 2 Болница „Аџибадем Систина“, Скопје, РС Македонија
}

Акутното воспаление на перитонеалната мембрана претставува главна компликација на перитонеалната дијализа во третманот на болните со хронична бубрежна болест. Целта на студијата беше да се анализира ратата на акутни перитонити, етиологијата, исходот и нивната асоцијацијата со преживувањето на пациентите на перитонеална дијализа (ПД). Дизајн на студијата: ретроспективна епидемиошка студија. Во одделот за перитонеална дијализа на ЈЗУ Клиника за нефрологија, од 1 јануари 1999 година до 31 декември 2018 година, вкупно се лекувани 96 пациенти со перитонеална дијализа. Вкупно 159 акутни епизоди на перитонит се регистрирани кај 54 (56,3 \%) од лекуваните пациенти. Пациентите беа поделени во две групи: група од 54 пациенти со дијагностицирана минимум една епизода на акутен перитонит и група од 42 пациенти кај кои не е регистрирана ниту една епизода на акутен перитонит. Ратата на перитонити беше 0,47 епизоди по пациент годишно. Најчести етиолошки причинители на перитонитите беа грам-позитивните бактерии $(53,5 \%)$. Клиничкиот исход од епизодите на перитонит беше: целосна резолуција на инфекцијата кај 84,9 \% од епизодите, присутна индикација да се извади катетерот за перитонеална дијализа кај 11,3 \% од епизодите и смртен исход кај 3,8 \% од епизодите на акутен перитонит. Kaplan-Meier статистичката анализа на преживување покажа дека групата пациенти со акутни перитонити се одликуваат со сигнификантно подолго преживување во споредба со групата пациенти без перитонити. Ризикот за смртност беше помал за 67 \% во групата на пациенти со перитонити во споредба со групата пациенти без перитонити (стапка на опасност: 0,33, 95 \% СI 0,19-0,57, P = 0,000). Превенцијата и третманот на инфекциите асоцирани со перитонеалната дијализа доведоа до намалување на нивната рата во светски рамки, со што се промовира перитонеалната дијализа како прв избор на модалитет за дијализно лекување на болните со хронична бубрежна болест.

Клучни зборови: перитонеална дијализа, инфекција, бактерии, перитонит, преживување 
